Pak. J. Agri. Sci., Vol. 53(1), 69-78; 2016

ISSN (Print) 0552-9034, ISSN (Online) 2076-0906

DOI: 10.21162/PAKJAS/16.4755

http://www.pakjas.com.pk

\title{
INTERACTIVE EFFECT OF SALINITY AND POTASSIUM ON GROWTH, BIOCHEMICAL PARAMETERS, PROTEIN AND OIL QUALITY OF SOYBEAN GENOTYPES
}

\author{
Parveen $^{1}$, Muhammad Anwar-ul-Haq ${ }^{1, *}$, Javaid Akhtar ${ }^{1}$ and Shahzad M.A. Basra ${ }^{2}$ \\ ${ }^{1}$ Institute of Soil and Environmental Sciences, University of Agriculture, Faisalabad-38040, Pakistan; \\ ${ }^{2}$ Department of Agronomy, University of Agriculture, Faisalabad-38040, Pakistan. \\ *Corresponding author's e-mail: haqgondal@gmail.com
}

\begin{abstract}
Potassium $\left(\mathrm{K}^{+}\right)$nutrition ensures growth and quality of crops both under normal and saline soils. In view of that a study was conducted to assess the impact of various doses of $\mathrm{K}^{+}$on growth, bio-chemicals, protein and oil contents of four soybean (Glycine max L.) genotypes under saline condition. Soybean genotypes were grown in pots having treatment combination of salinity (control, 6 and $12 \mathrm{dS} \mathrm{m}^{-1}$ ) and $\mathrm{K}^{+}$doses (control, 50 and $75 \mathrm{~kg} \mathrm{ha}^{-1}$ ). The results showed that sufficient $\mathrm{K}^{+}$nutrition enhanced plant growth, biomass production, protein and oil percentage of soybean genotypes both in normal and saline condition. Water relation in plant as well as chlorophyll contents and leaf area improved with the application of potassium under salinity stress. Across $\mathrm{K}^{+}$application rates, all soybean genotypes significantly varied from each other. $\mathrm{K}^{+}$ accumulation was positively correlated with growth and other parameters of soybean genotypes, but these relationships were stronger in case of genotypes No.62 and No 13 as compared to Ajmeri and William-82 genotypes. Soybean genotypes No. 62 and No. 13 classified as potassium efficient genotypes while Ajmeri and William-82 categorized as potassium inefficient genotypes on the basis of growth and $\mathrm{K}$ uptake.
\end{abstract}

Keywords: Salinity, Potassium, Protein, antioxidant enzymes, Oil, Soybean

\section{INTRODUCTION}

Soybean is one of the most important oil seed crop that is multi-dimensional in its uses however it contains the best quality protein due to which it is being called as "the meat that is grown on plant". The seeds of soybean contain $50 \%$ good quality protein, $17-24 \%$ highly palatable oil containing zero cholesterol level, 6\% ash, 29\% sugars (Essa and AlAni, 2001; Agarwal, 2007; Shi and Cai, 2010). Except above all benefits, it is also a good source of polyunsaturated fat, fibers, vitamins and contains a small amount of minerals and energy (Krishnan, 2001). It contains about $85 \%$ of the world oil seed and placed in group of the oil seed crop. Soybean seed is processed into soybean meal and vegetable oil. Soybean may be a significant source for biofuel production (Anonymous, 2009). In 2009-2010 the total demand of food oil in Pakistan was 4.125 million tons and about $65 \%$ of the country requirement of edible oil was met through imports (Akinori et al., 2000; Balasubramaniyan et al., 2001; Anonymous, 2012).

Agriculture sector is facing various threats today, one of the major stresses among all is salinity which is caused due to high temperature, less rainfall, poor quality water and soil management and eventually high evapotranspiration (Neto $e t$ al., 2006; Flowers and Colmer, 2008). The affected area due to salinity in all over the world is about $45 \mathrm{~m}$ ha of irrigated regions and about $1.5 \mathrm{~m}$ ha cannot give productions due to high salinity (Munns and Tester, 2008). In Pakistan the cultivated land of $6.67 \mathrm{~m}$ ha is saline among which Punjab province covers an area of about $2.67 \mathrm{~m}$ ha (Ghafoor et al., 2004). In world over, salinity has damaged about $7 \%$ of agricultural area, out of which 3\% land is considered highly saline and eventually this area is expected to increase up to $20 \%$ in the future.

Continuous reduction of cultivable area due to salinity and increasing population of the world is causing immense pressure on agriculture to ensure food security. Therefore, the current decade's explorations are going to emphasize the response of plants in salt stress (Zora, 2006). Plant species show different behavior in salt stress in order to exclude salts from their cells or to endure their presence within the cells by involving many kinds of physiological and biochemical changes. Generally, there are two approaches for increasing the production of crops from salt affected soils: first reclamation of these soils and second by introduction of salt tolerant genotypes (Blumwald et al., 2004; Yilmaz et al., 2004). The former approach is not practicable due to wide salt-affected areas, insufficient availability of good quality water, soil permeability and high cost of amendments (Akhtar et al., 2010). Therefore, we are left with choice of introducing salt tolerant genotypes in these problematic soils and also finding the options to improve salt tolerance to certain levels that can minimize all these problems (Iqbal et al., 2007).It is observed that the salt 
sensitive plants does not maintain a higher $\mathrm{K}^{+} / \mathrm{Na}^{+}$ratio, as it is needed while salt tolerant plants conserve a high $\mathrm{K}^{+}$ content (Rejili et al., 2007). With the increasing concentration of salts in the plants (stem tissues) of Spina Christi Z.an increased amount of $\mathrm{N}$ and $\mathrm{P}$ were observed. However, salinity caused by $\mathrm{NaCl}$ had hardly been the source of reducing $\mathrm{K}^{+} / \mathrm{Na}^{+}$ratio in different parts of plants (Sohail et al., 2010).

Potassium is one of the major components of plant tissue which makes about $1-10 \%$ of dry matter (Epstein and Bloom, 2005). Potassium $\left(\mathrm{K}^{+}\right)$plays a fundamental role in balancing turgor potential, membrane potential, stoma movement, tropisms and enzymes activation (Cherel, 2004). Both elements potassium and sodium are found together in the soil solution. Both of these possess positive charge on them and hence during reciprocal absorption and translocation, they employ antagonistic or synergistic effects under salinity stress (Hussain et al., 2013). Eventually, maintained amount of $\mathrm{K}^{+} / \mathrm{Na}^{+}$ratio is precisely critical for the working stomatal function, for the synthesis of protein, cell osmoregulation, activation of enzymes, and turgor maintenance (Shabala et al., 2003).

Application of $\mathrm{K}^{+}$under salinity lowers the creation of reactive oxygen species while activities of antioxidative enzymes containing catalase, superoxide dismutase and peroxidase enhanced during stress (Liang et al., 2007; Abbasi, et al., 2015). Increased accumulation of $\mathrm{K}^{+}$in salinity stressed plants is important for maintenance of increased cellular $\mathrm{K}^{+} / \mathrm{Na}^{+}$ratio. Supplementary $\mathrm{K}^{+}$can reduce the adverse effects of increasing salinity (Kavitha et al., 2012). Soybean responds positively to potassium application in regulation of oil and protein contents in seeds (Tiwari et al., 2002).

In view of above discussions, the current research work was conducted with objectives to investigate the behavior of $\mathrm{K}^{+}$ application on the performance, antioxidant enzymes, protein and oil quality of soybean genotypes during salinity stress.

\section{MATERIALS AND METHODS}

Experimental conditions: A pot study was conducted in University of Agriculture, Faisalabad-Pakistan by using four soybean genotypes (Glycine max L.) including; No. 62, No. 13, William and Ajmeri. In blank earthen pots filled with pulverized $12 \mathrm{~kg}$ soil $\left(\mathrm{EC}=1.5 \mathrm{dS} \mathrm{m}^{-1}, \mathrm{pH}=8.23, \mathrm{SAR}=6.74\right.$ $\left.\left.(\mathrm{mmol} \mathrm{L})^{-1}\right)^{1 / 2}\right)$ soil texture=sandy clay loam) after mixing with required fertilizer and potassium dose, the soybean seeds were sown at $2 \mathrm{~cm}$ depth and their response was determined under different levels of $\mathrm{NaCl}$ (control, 6 and 12 $\mathrm{dS} \mathrm{m}^{-1}$ ) alone and in combination with $\mathrm{K}_{2} \mathrm{SO}_{4}$.Seven treatments were applied to soybean viz. T1: Control, T2: EC $6 \mathrm{dS} \mathrm{m}{ }^{-1}$, T3: EC $12 \mathrm{dS} \mathrm{m}{ }^{-1}$, T4: EC $6 \mathrm{dS} \mathrm{m}{ }^{-1}+50 \mathrm{~kg} \mathrm{ha}^{-1}$ $\mathrm{K}^{+}$, T5: EC $6 \mathrm{dS} \mathrm{m}{ }^{-1}+75 \mathrm{~kg} \mathrm{ha}^{-1} \mathrm{~K}^{+}$, T6: EC $12 \mathrm{dS} \mathrm{m}{ }^{-1}+50$ $\mathrm{kg} \mathrm{ha} \mathrm{K}^{-1}$, T7: EC $12 \mathrm{dS} \mathrm{m} \mathrm{m}^{-1}+75 \mathrm{~kg} \mathrm{ha}^{-1} \mathrm{~K}^{+}$. The experimental design was CRD using factorial arrangement with four replications. The total period of the experiment was 4 months. The tap water was used for irrigation $(\mathrm{EC}=$ $\left.0.88 \mathrm{dS} \mathrm{m} \mathrm{m}^{-1}, \mathrm{RSC}=0.75 \mathrm{me} \mathrm{L}^{-1}, \mathrm{SAR}=2.5\right)$ to the pots whenever irrigation necessary.

Following parameters were determined: Relative water contents (RWC) (Sairam et al., 2002), membrane stability index (MSI) (Sairam et al., 2002), gas exchange parameters (Infrared gas analyzer), chlorophyll contents (SPAD chlorophyll meter), leaf area (leaf area meter), antioxidant enzymes (Giannopolitis and Ries, 1977; Chance and Maehly, 1955) and oil and protein contents (Hymowitz et al., 1974) and plants were harvested for further analysis.

Statistical Analysis: All information presented in this experiment was means of four replications. Results were interpreted by using a statistical package, statistix $8.1 \circledR$.

\section{RESULTS}

Growth parameters: Salinity stress reduced fresh and dry biomass in all soybean genotypes, while application of potassium was helpful to survive during stress (Fig. 1). In all soybean genotypes salinity stress $\left(12 \mathrm{dS} \mathrm{m}^{-1}\right)$ caused reduction in shoot fresh $(\mathrm{LSD}=1.57)$ and dry weight $(\mathrm{LSD}=0.62)$, root fresh $(\mathrm{LSD}=0.93)$ and dry weights $(\mathrm{LSD}=0.10)$ at $5 \%$ probability level. Among all treatments the treatment with maximum $\mathrm{K}^{+}$dose $(9 \mathrm{mM})$ with $6 \mathrm{dSm}^{-1}$ salinity stress $(\mathrm{NaCl})$ performed better after control and showed maximum shoot fresh weight (31.84 g), shoot dry weight $(7.86 \mathrm{~g})$, root fresh weight $(7.86 \mathrm{~g})$ and root dry weight $(1.56 \mathrm{~g})$ in No. 62 followed by No.13 while minimum shoot fresh weight $(8.77 \mathrm{~g})$, shoot dry weight $(2.58 \mathrm{~g})$, root fresh weight $(2.58 \mathrm{~g})$ and root dry weight $(0.42$ g) was observed in Ajmeri followed by William-82.Among all treatments the treatment with $\mathrm{K}^{+}$dose $(9 \mathrm{mM})$ at salinity $6 \mathrm{dSm}^{-1}$ performed better after control and showed maximum shoot fresh and dry weights. However, $\mathrm{K}^{+}$ application improved all plant growth attributed in all soybean genotypes while best response towards $\mathrm{K}^{+}$ application was detected in soybean genotype No. 62 . Moreover, in all soybean genotypes $75 \mathrm{~kg} \mathrm{~K}^{+} \mathrm{ha}^{-1}$ dose was found better at $6 \mathrm{dS} \mathrm{m} \mathrm{m}^{-1}$ salinity in reducing the adverse effects of salinity. Effect of salinity and potassium application on shoot and root length $(\mathrm{LSD}=3.70$ and 1.76 respectively) at $5 \%$ probability level in four soybean genotypes shown in (Figure 1). Accumulation of $\mathrm{NaCl}$ caused significant reduction in shoot length and root length in all soybean genotypes than control. The greater reductions in these factors were observed in salt sensitive soybean genotypes than salt tolerant soybean genotypes on the basis of potassium use efficiency. But, potassium application considerably minimized the negative effects of salinity both in salt tolerant and salt sensitive soybean genotypes especially at higher $75 \mathrm{~kg} \mathrm{ha}^{-1} \mathrm{~K}^{+}$level. 

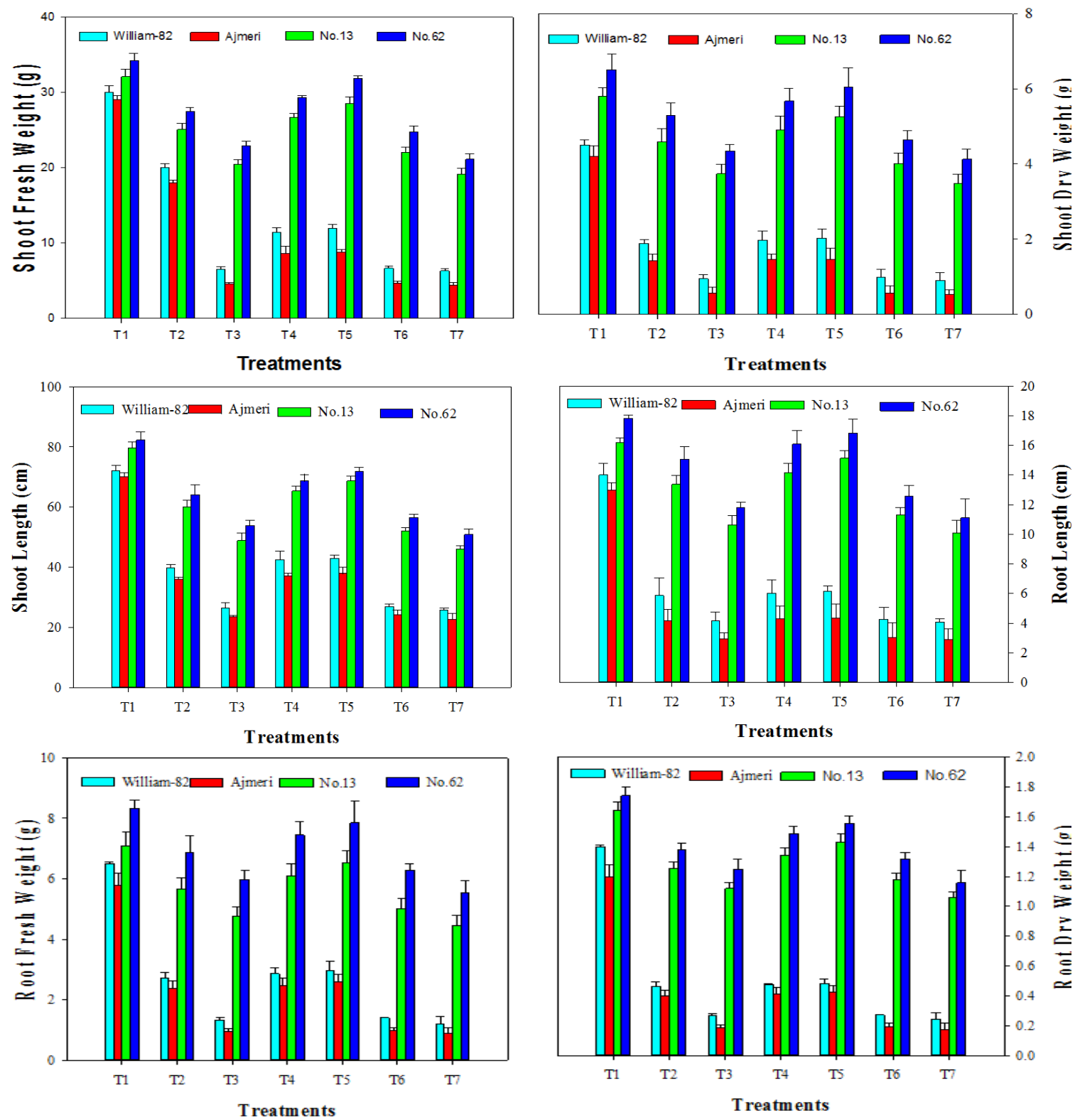

Figure 1. Effect of salinity and potassium application on growth of soybean genotypes.

(T1: Control, T2: EC $6 \mathrm{dS} \mathrm{m}{ }^{-1}$, T3: EC $12 \mathrm{dS} \mathrm{m}^{-1}$, T4: EC $6 \mathrm{dS} \mathrm{m}{ }^{-1}+50 \mathrm{Kg} \mathrm{ha}^{-1} \mathrm{~K}^{+}$, T5: EC $6 \mathrm{dS} \mathrm{m}^{-1}+75 \mathrm{Kg}$ $\mathrm{ha}^{-1} \mathrm{~K}^{+}$, T6: EC $12 \mathrm{dS} \mathrm{m}{ }^{-1}+50 \mathrm{Kg} \mathrm{ha}^{-1} \mathrm{~K}^{+}$, T7: EC $12 \mathrm{dS} \mathrm{m}^{-1}+75 \mathrm{Kg} \mathrm{ha}^{-1} \mathrm{~K}^{+}$)

Leaf area, chlorophyll contents, MSI and RWC: Leaf area, chlorophyll contents, relative water contents and membrane stability index expressed in Fig. 2. Reduction in leaf area $(\mathrm{LSD}=7.13)$, chlorophyll contents $(\mathrm{LSD}=2.89)$, membrane stability index $(\mathrm{LSD}=4.46)$, and relative water contents $(\mathrm{LSD}=3.89)$ parameters at $5 \%$ probability was recorded in all soybean genotypes with induced salinity $\left(6\right.$ and $12 \mathrm{dS} \mathrm{m}^{-}$ $\left.{ }^{1}\right)$ levels. Among all the treatments which were used, reduction was maximum in pots which were supplied with combinations of maximum dose of $\mathrm{K}^{+}$and $\mathrm{NaCl}\left(\mathrm{K}^{+} 75 \mathrm{~kg}\right.$ $\left.\mathrm{ha}^{-1}+12 \mathrm{dS} \mathrm{m}^{-1} \mathrm{NaCl}\right)$. In response of treatment $6 \mathrm{dS} \mathrm{m}$ ${ }^{1} \mathrm{NaCl}$ induced salinity with $9 \mathrm{mM} \mathrm{K} \mathrm{K}^{+}$application No. 62 exhibited percent of control 94.99 and $97 \%$ followed by No. 13 with 91, 95 and 96\% while Ajmeri showed 63, 81, 80\% followed by William-82 with 67,83 and $83 \%$ in leaf area, relative water contents and membrane stability index respectively. Reduction was maximum in potassium inefficient soybean genotypes (Ajmeri and William-82) than potassium efficient genotypes (No. 62 and No. 13). Plants showed positive improvement in leaf area, chlorophyll 

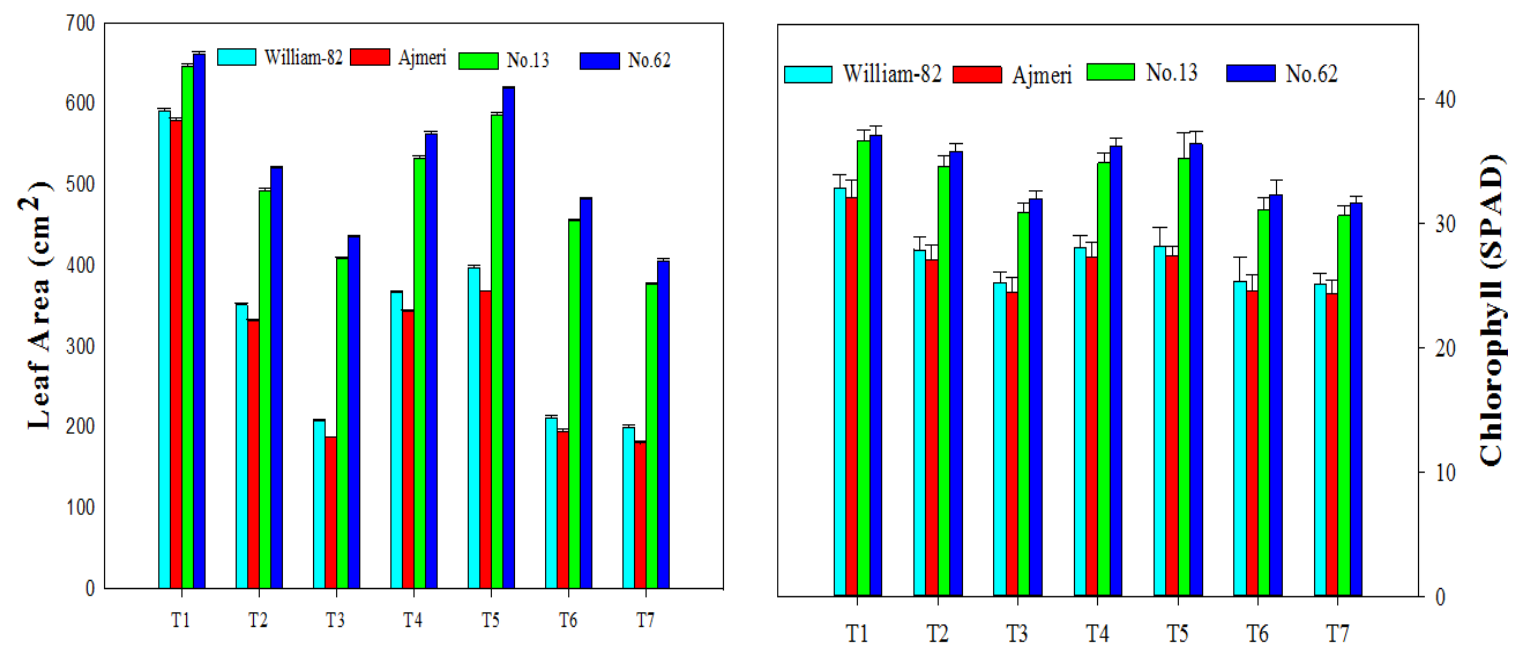

Treatments

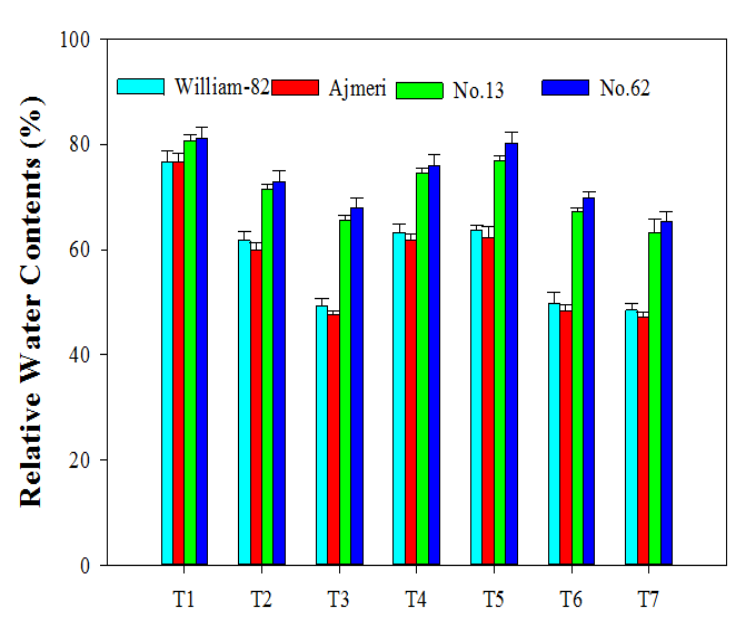

Treatments

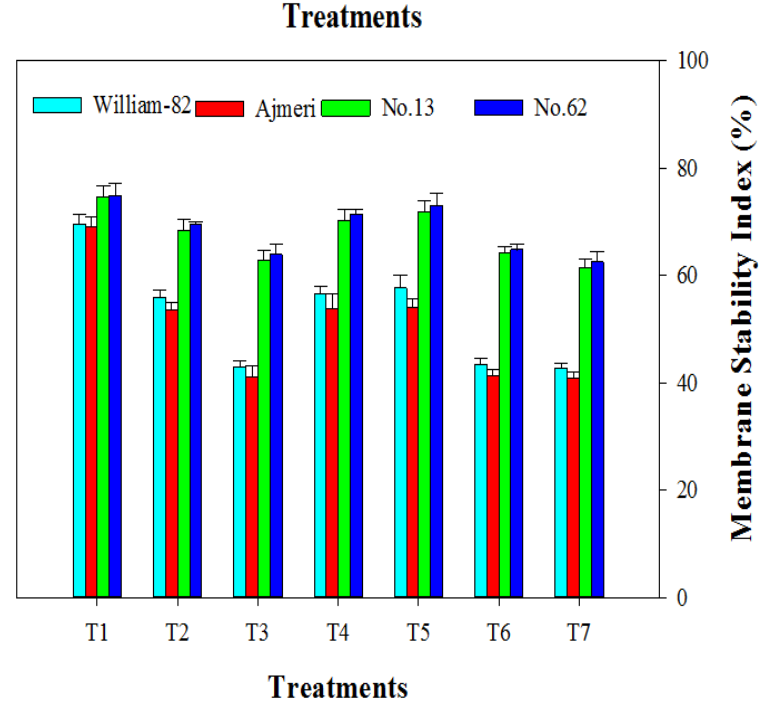

Figure 2. Effect of salinity and potassium application on leaf area, chlorophyll contents and leaf water relations. (T1: Control, T2: EC $6 \mathrm{dS} \mathrm{m}{ }^{-1}$, T3: EC $12 \mathrm{dS} \mathrm{m}^{-1}$, T4: EC $6 \mathrm{dS} \mathrm{m}^{-1}+50 \mathrm{Kg} \mathrm{h}^{-1} \mathrm{~K}^{+}$, T5: EC $6 \mathrm{dS} \mathrm{m}^{-1}+75 \mathrm{Kg}$ ha $^{-1} \mathrm{~K}^{+}$, T6: EC $12 \mathrm{dS} \mathrm{m}{ }^{-1}+50 \mathrm{Kg} \mathrm{ha}^{-1} \mathrm{~K}^{+}$, T7: EC $12 \mathrm{dS} \mathrm{m}{ }^{-1}+75 \mathrm{Kg} \mathrm{ha}^{-1} \mathrm{~K}^{+}$)

contents, relative water contents and membrane stability index at $5 \%$ probability level in response to $\mathrm{K}^{+}$application and the level of enhancement was better in salt tolerant soybean genotypes than salt sensitive. The reaction of maximum dose of $\mathrm{K}^{+}$application with $12 \mathrm{dS} \mathrm{m}^{-1} \mathrm{NaCl}$ was either negligible or bad in all soybean genotypes.

Gas exchange parameters: Gas exchange parameters were determined in response to salinity and potassium application. Reduction was greater at maximum salinity in photosynthetic rate $(\mathrm{LSD}=1.48)$, transpiration rate $(\mathrm{LSD}=0.89)$, stomatatal conductance $(\mathrm{LSD}=0.04)$, and substomatal conductance $(\mathrm{LSD}=5.41)$ at $5 \%$ probability level while potassium application was useful in improving salinity tolerance (Fig. 3.). The improvement of potassium was relatively less with $12 \mathrm{dS} \mathrm{m}^{-1}$ salinity stress $(\mathrm{NaCl})$ than with $6 \mathrm{dS} \mathrm{m}^{-1}$ salinity stress $(\mathrm{NaCl})$. Soybean genotype No. 62 showed percent of control 87, 90, 98 and $94 \%$ followed by No. 13 with 82, 88, 97 and 93\% while Ajmeri showed 56, 61,74 and $71 \%$ followed by William-82 with $59,63,77$ and $70 \%$ in photosynthesis rate, transpiration rate, stomatal conductance and intercellular $\mathrm{CO}_{2}$ Conc. respectively in combined application of $6 \mathrm{dS} \mathrm{m}^{-1}$ salt stress with $75 \mathrm{~kg} \mathrm{ha}^{-1}$ K.However maximum reduction in all soybean genotypes was measured at $75 \mathrm{~kg} \mathrm{ha}^{-1} \mathrm{~K}^{+}$and $12 \mathrm{dS} \mathrm{m} \mathrm{m}^{-1}(\mathrm{NaCl})$ combine application. The reaction of all the soybean genotypes was dissimilar due to their diverse genetic potential of salt tolerance. No. 62 followed by No. 13 presented fewer declines in gas exchange parameters in response to salt stress than with Ajmeri and William-82. 

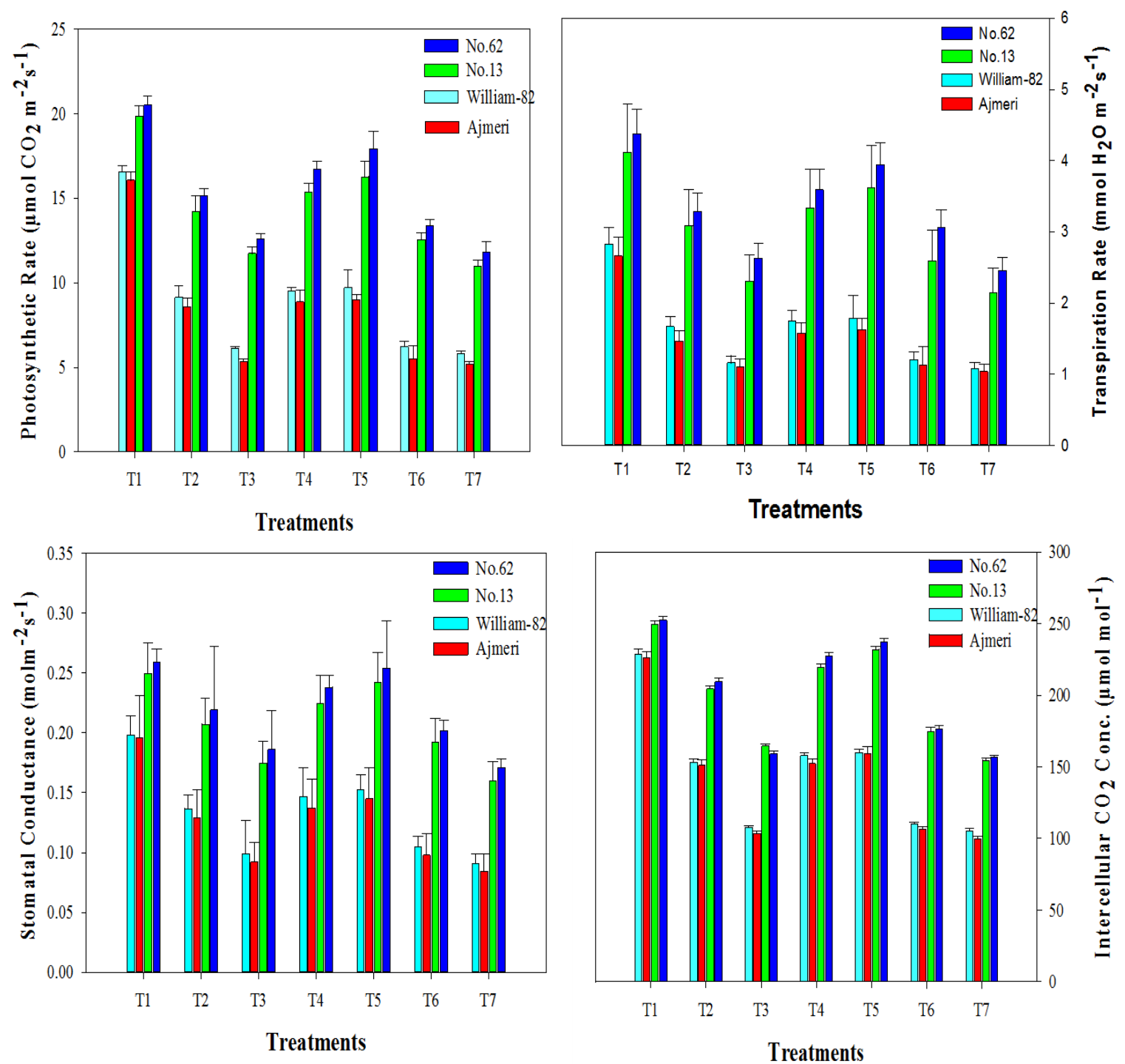

Figure 3. Effect of salinity and potassium application on gas exchange parameters of soybean genotypes. (T1: Control, T2: EC $6 \mathrm{dS} \mathrm{m}{ }^{-1}$, T3: EC $12 \mathrm{dS} \mathrm{m}^{-1}$, T4: EC $6 \mathrm{dS} \mathrm{m}^{-1}+50 \mathrm{Kg} \mathrm{ha}^{-1} \mathrm{~K}^{+}$, T5: EC $6 \mathrm{dS} \mathrm{m}^{-1}+75 \mathrm{Kg}$ ha ${ }^{-1} \mathrm{~K}^{+}$, T6: EC $12 \mathrm{dS} \mathrm{m}^{-1}+50 \mathrm{Kg} \mathrm{ha}^{-1} \mathrm{~K}^{+}$, T7: EC $12 \mathrm{dS} \mathrm{m}{ }^{-1}+75 \mathrm{Kg} \mathrm{ha}^{-1} \mathrm{~K}^{+}$)

Improvement of gas exchange parameters was more at higher dose of $\mathrm{K}$ at $6 \mathrm{dS} \mathrm{m}^{-1}$ salinity stress.

Antioxidants enzymes: Antioxidant enzymes were measured in all soybean genotypes under induced salt stress $(\mathrm{NaCl})$ and potassium application. The activity of SOD was positively enhanced in salt tolerant soybean genotypes (No. 62 and No.13) but no improvement was measured in salt sensitive soybean genotypes (Ajmeri and William-82) at 6 $\mathrm{dS} \mathrm{m} \mathrm{m}^{-1}$ salt stress alone and also with application of $\mathrm{K}$ (Table 1.). At maximum salinity level, SOD activity reduced in all Ajmeri and William-82 than control. The activities of POD and CAT were reduced at low salinity level than control in all soybean genotypes. But at low salinity level, CAT and
POD activities reduced but reduction was less in salt tolerant soybean genotypes than salt sensitive soybean genotypes at high salinity level. Application of $\mathrm{K}^{+}$improved CAT activity in salt tolerant soybean genotypes in both salinity and $\mathrm{K}^{+}$ levels. Obvious increment in activities of SOD and POD were recorded at low salinity level at high potassium level $\left(75 \mathrm{~kg} \mathrm{ha}^{-1} \mathrm{~K}\right)$ in soybean genotypes. However, no major effect of application of $\mathrm{K}^{+}$was perceived on SOD, POD and CAT activities in salt sensitive soybean genotypes.

Soybean yield, protein and oil: Soybean yield, Protein and oil concentration of soybean genotypes increased with succeeding seed development under saline and non-saline conditions. Under control or normal conditions higher 
Table 1. Effect of salt treatment and potassium application on superoxide dismutase (SOD), peroxidase (POD) and catalase (CAT) of soybean genotypes

\begin{tabular}{|c|c|c|c|c|}
\hline Varieties & Treatments & SOD (unit $\mathrm{mg}^{-1}$ of protein) & POD (unit $\mathrm{mg}^{-1}$ of protein) & CAT (unit $\mathrm{mg}^{-1}$ of protein) \\
\hline \multirow[t]{7}{*}{ No. 62} & T1 & $51.43 \pm 1.04 \mathrm{hi}$ & $70.75 \pm 0.85 \mathrm{e}$ & $10.23 \pm 0.73 \mathrm{c}$ \\
\hline & $\mathrm{T} 2$ & $62.11 \pm 1.06(121) \mathrm{d}$ & $82.57 \pm(117) \mathrm{c}$ & $9.82 \pm 0.70(96) \mathrm{cd}$ \\
\hline & T3 & $54.75 \pm 0.87$ (106)fg & $66.71 \pm(94) \mathrm{e}$ & $8.38 \pm 0.60(82)$ fgh \\
\hline & $\mathrm{T} 4$ & $67.31 \pm 0.71(131) b$ & $89.63 \pm(127) a b$ & $11.45 \pm 0.82(112) \mathrm{ab}$ \\
\hline & T5 & $71.52 \pm 0.72(139) \mathrm{a}$ & $91.39 \pm(129) \mathrm{a}$ & $12.17 \pm 0.87(119) \mathrm{a}$ \\
\hline & T6 & $55.81 \pm 0.90$ (109)ef & $69.26 \pm(98) \mathrm{e}$ & $8.69 \pm 0.62$ (85)efg \\
\hline & $\mathrm{T} 7$ & $49.87 \pm 1.25$ (97)hij & $61.44 \pm(87) f$ & $8.03 \pm 0.31$ (79)fghijk \\
\hline \multirow[t]{7}{*}{ No. 13} & $\mathrm{~T} 1$ & $49.27 \pm 1.18 \mathrm{ij}$ & $67.75 \pm 1.11 \mathrm{e}$ & $9.58 \pm 0.22 \mathrm{cde}$ \\
\hline & $\mathrm{T} 2$ & $58.51 \pm 0.26(119) \mathrm{e}$ & $75.64 \pm 0.60(112) \mathrm{d}$ & $9.00 \pm 0.20(94) \mathrm{def}$ \\
\hline & $\mathrm{T} 3$ & $51.38 \pm 0.90(104) \mathrm{hi}$ & $59.58 \pm 1.42(88) \mathrm{fg}$ & $7.85 \pm 0.18$ (82)ghijkl \\
\hline & $\mathrm{T} 4$ & $63.52 \pm 1.72(129) \mathrm{cd}$ & $86.78 \pm 0.89(128) b c$ & $10.53 \pm 0.24(110) b c$ \\
\hline & T5 & $65.64 \pm 1.16(133) b c$ & $91.07 \pm 2.28(134) \mathrm{ab}$ & $11.49 \pm 0.26(120) a b$ \\
\hline & T6 & $52.50 \pm 0.89(107) \mathrm{gh}$ & $62.18 \pm 1.05(92) \mathrm{f}$ & $8.23 \pm 0.19(86)$ fghi \\
\hline & $\mathrm{T} 7$ & $47.31 \pm 0.85(96) \mathrm{jk}$ & $56.75 \pm 1.38(84) \mathrm{gh}$ & $7.21 \pm 0.14(75) \mathrm{jklm}$ \\
\hline \multirow[t]{7}{*}{ William 82} & $\mathrm{~T} 1$ & $40.17 \pm 0.81 \mathrm{mn}$ & $45.25 \pm 1.11 \mathrm{jk}$ & $7.45 \pm 0.15$ hijklm \\
\hline & $\mathrm{T} 2$ & $45.04 \pm 0.68(112) \mathrm{kl}$ & $49.67 \pm 1.66(110) \mathrm{ij}$ & $7.65 \pm 0.10(103) \mathrm{hijkl}$ \\
\hline & T3 & $39.15 \pm 0.52$ (97)nop & $37.62 \pm 1.24(83) 1$ & $5.07 \pm 0.10(68) \mathrm{no}$ \\
\hline & $\mathrm{T} 4$ & $47.62 \pm 0.73(119) \mathrm{jk}$ & $47.62 \pm 2.46(105) \mathrm{jk}$ & $8.12 \pm 0.16$ (109)fghij \\
\hline & T5 & $50.82 \pm 1.09(127) \mathrm{hi}$ & $52.86 \pm 0.80(117) \mathrm{hi}$ & $8.42 \pm 0.17$ (113)fgh \\
\hline & T6 & $39.78 \pm 1.70$ (99)no & $37.84 \pm 1.50(84) 1$ & $5.14 \pm 0.10(69) \mathrm{n}$ \\
\hline & $\mathrm{T} 7$ & $36.24 \pm 1.03(90) \mathrm{q}$ & $34.67 \pm 1.11(77) 1 \mathrm{~lm}$ & $4.77 \pm 0.12(64) \mathrm{no}$ \\
\hline \multirow[t]{7}{*}{ Ajmeri } & $\mathrm{T} 1$ & $37.09 \pm 0.88 \mathrm{opq}$ & $44.25 \pm 1.11 \mathrm{k}$ & $6.55 \pm 0.13 \mathrm{~m}$ \\
\hline & $\mathrm{T} 2$ & $40.97 \pm 1.08(110) \mathrm{mn}$ & $46.82 \pm 1.30(106) \mathrm{jk}$ & $6.87 \pm 0.12(105) 1 \mathrm{~m}$ \\
\hline & T3 & $35.51 \pm 0.87(96) \mathrm{qr}$ & $30.91 \pm 0.99(70) \mathrm{mn}$ & $4.39 \pm 0.09(67) \mathrm{no}$ \\
\hline & $\mathrm{T} 4$ & $42.62 \pm 1.03(115) 1 \mathrm{~m}$ & $46.23 \pm 2.07(104) \mathrm{jk}$ & $7.07 \pm 0.14(108) \mathrm{klm}$ \\
\hline & T5 & $44.29 \pm 0.89(119) 1$ & $47.26 \pm 1.41(107) \mathrm{jk}$ & $7.34 \pm 0.15$ (112)ijklm \\
\hline & T6 & $36.92 \pm 0.64(100) p q$ & $34.76 \pm 1.53(79) \mathrm{lm}$ & $4.52 \pm 0.09(69) \mathrm{no}$ \\
\hline & $\mathrm{T} 7$ & $33.38 \pm 0.73(90) \mathrm{r}$ & $28.78 \pm 0.65(65) \mathrm{n}$ & $4.13 \pm 0.08(63) \mathrm{o}$ \\
\hline
\end{tabular}

T1: Control, T2: EC $6 \mathrm{dS} \mathrm{m}{ }^{-1}$, T3: EC $12 \mathrm{dS} \mathrm{m}{ }^{-1}$, T4: EC 6 dS m${ }^{-1}+50 \mathrm{Kg} \mathrm{ha}^{-1} \mathrm{~K}^{+}$, T5: EC $6 \mathrm{dS} \mathrm{m}^{-1}+75 \mathrm{Kg} \mathrm{ha}^{-1} \mathrm{~K}^{+}$, T6: EC $12 \mathrm{dS} \mathrm{m}^{-1}+50 \mathrm{Kg} \mathrm{ha}^{-1} \mathrm{~K}^{+}$, T7: EC $12 \mathrm{dS} \mathrm{m}^{-1}+75 \mathrm{Kg} \mathrm{ha}^{-1} \mathrm{~K}^{+}$.

Each value is an average of 4 replicates \pm S.E., and values in parenthesis are the percent of control.

contents of protein and oil contents were measured while under saline condition reduction was higher. In improving the protein $(\mathrm{LSD}=2.20)$ and oil concentration $(\mathrm{LSD}=0.57)$ at $5 \%$ probability level the potassium application was helpful in all soybean genotypes but smallest enhancement was measured at maximum dose of $\mathrm{K}$ with highest salinity level. Though both protein and oil concentration reduced with increasing salinity $(\mathrm{NaCl})$ extent (Table 2 .).

\section{DISCUSSION}

Genetic differences in plants provide a valued tool in assortment of genotypes with required traits (Misra and Dwivedi, 2004). It is noticeable that salinity stress adversely affects all the morphological, ionic, biochemical and physiological parameters (Sairam et al., 2002; Zhu, 2002;
Hajer et al., 2006; Chen et al., 2013; Abbasi et al., 2015). Potassium application significantly enhanced plant growth, gas exchange factors, $\mathrm{K}^{+} / \mathrm{Na}^{+}$ratio and antioxidant enzymes activities in all soybean genotypes and minimized the adverse effects of salt stress (Chen et al., 2007; Zheng et al., 2008; Abbasi et al., 2014). The results also showed that soybean genotype No. 62 and No. 13 are comparatively more salt tolerant and potassium efficient than soybean genotypes Ajmeri and William-82. There was significant reduction of plant biomass, leaf area, chlorophyll contents, MSI, RWC, antioxidant enzymes, protein and oil contents in all soybean genotypes at all the levels of salinity. These findings are also comparable with previous results which confirmed that salinity caused reduction in plant growth due to osmotic stress, ionic toxicity and less cell wall extensibility (Hajer et al., 2006; Abbasi, et al., 2015). The 
Table 2. Effect of salt treatment and potassium application on yield, protein and oil contents of soybean genotypes.

\begin{tabular}{|c|c|c|c|c|}
\hline Varieties & Treatments & Pods per plant (Yield) & Protein $(\%$ DM) & Oil (\% DM) \\
\hline \multirow[t]{7}{*}{ No. 62} & T1 & $17.25 \pm 1.10 \mathrm{a}$ & $45.56 \pm 0.74 a$ & $19.01 \pm 0.62 \mathrm{a}$ \\
\hline & $\mathrm{T} 2$ & $11.75 \pm 0.85(68) b c$ & $40.21 \pm 0.75(88) \mathrm{de}$ & $18.06 \pm 0.59(95) \mathrm{bcd}$ \\
\hline & T3 & $7.88 \pm 0.43$ (46)fghi & $34.74 \pm 0.65$ (76)hi & $17.11 \pm 0.56(90) \mathrm{gh}$ \\
\hline & $\mathrm{T} 4$ & $12.25 \pm 0.63(71) b c$ & $42.10 \pm 0.64(92) \mathrm{cd}$ & $18.25 \pm 0.60(96) b c$ \\
\hline & T5 & $13.00 \pm 0.41(75) \mathrm{b}$ & $43.34 \pm 0.39(95) b c$ & $18.44 \pm 0.60(97) \mathrm{ab}$ \\
\hline & T6 & $8.75 \pm 0.75$ (51)fgh & $39.37 \pm 0.57(86)$ ef & $17.49 \pm 0.57(92) \mathrm{defg}$ \\
\hline & $\mathrm{T} 7$ & $7.75 \pm 0.63$ (45)fghi & $32.06 \pm 0.87$ (70)klmn & $16.92 \pm 0.55(89) \mathrm{ghi}$ \\
\hline \multirow[t]{7}{*}{ No. 13} & $\mathrm{~T} 1$ & $16.00 \pm 0.91 \mathrm{a}$ & $44.56 \pm 1.28 \mathrm{ab}$ & $18.93 \pm 0.26 \mathrm{a}$ \\
\hline & $\mathrm{T} 2$ & $11.00 \pm 1.08(69) \mathrm{cde}$ & $38.32 \pm 1.10$ (86)ef & $17.79 \pm 0.24(94) \mathrm{cdef}$ \\
\hline & T3 & $7.13 \pm 0.52(45)$ ghij & $32.97 \pm 0.94$ (74)ijkl & $16.84 \pm 0.23(89) \mathrm{hi}$ \\
\hline & $\mathrm{T} 4$ & $11.50 \pm 0.65(72) \mathrm{bcd}$ & $40.10 \pm 1.15(90) \mathrm{de}$ & $17.98 \pm 0.24$ (95)bcde \\
\hline & T5 & $11.88 \pm 0.43(74) b c$ & $42.19 \pm 1.06(95) \mathrm{cd}$ & $18.17 \pm 0.25(96) b c$ \\
\hline & T6 & $8.00 \pm 0.71(50) \mathrm{fgh}$ & $35.93 \pm 0.50(81) \mathrm{gh}$ & $17.22 \pm 0.23(91) \mathrm{fgh}$ \\
\hline & $\mathrm{T} 7$ & $7.00 \pm 0.41$ (44)hijk & $30.30 \pm 0.87(68) \mathrm{mno}$ & $16.65 \pm 0.23(88)$ hij \\
\hline \multirow[t]{7}{*}{ William 82} & $\mathrm{~T} 1$ & $15.75 \pm 0.85 \mathrm{a}$ & $44.90 \pm 0.77 \mathrm{ef}$ & $17.83 \pm 0.35 \mathrm{cde}$ \\
\hline & $\mathrm{T} 2$ & $8.75 \pm 0.48(56) f g h$ & $35.02 \pm 0.60$ (78)lmno & $16.04 \pm 0.31(90) \mathrm{kl}$ \\
\hline & T3 & $5.68 \pm 0.71(36) \mathrm{jk}$ & $30.09 \pm 0.52(67) q$ & $15.15 \pm 0.30(85) \mathrm{mn}$ \\
\hline & $\mathrm{T} 4$ & $9.25 \pm 0.63$ (59)ef & $37.27 \pm 0.64(83) \mathrm{jklm}$ & $16.22 \pm 0.32(91) \mathrm{jk}$ \\
\hline & $\mathrm{T} 5$ & $9.63 \pm 0.62(61) \mathrm{def}$ & $39.51 \pm 0.68(88) h i j$ & $16.40 \pm 0.32(92) \mathrm{ijk}$ \\
\hline & T6 & $6.00 \pm 0.41(38) \mathrm{ijk}$ & $33.68 \pm 0.58$ (75)op & $15.33 \pm 0.30(86) \mathrm{m}$ \\
\hline & $\mathrm{T} 7$ & $5.43 \pm 0.59(34) \mathrm{jk}$ & $27.39 \pm 0.47(61) \mathrm{r}$ & $14.97 \pm 0.29(84) \mathrm{mno}$ \\
\hline \multirow[t]{7}{*}{ Ajmeri } & $\mathrm{T} 1$ & $15.75 \pm 0.85 \mathrm{a}$ & $40.21 \pm 0.46 a b$ & $17.47 \pm 0.35 \mathrm{efg}$ \\
\hline & $\mathrm{T} 2$ & $8.50 \pm 0.50$ (54)fgh & $30.84 \pm 0.85$ (77)hi & $15.37 \pm 0.31(88) \mathrm{m}$ \\
\hline & $\mathrm{T} 3$ & $5.43 \pm 0.83(34) \mathrm{jk}$ & $26.22 \pm 0.72(65) \mathrm{no}$ & $14.50 \pm 0.29(83) \mathrm{op}$ \\
\hline & $\mathrm{T} 4$ & $9.00 \pm 0.41(57) \mathrm{fg}$ & $32.39 \pm 0.89(81) f g$ & $15.37 \pm 0.31(88) \mathrm{m}$ \\
\hline & T5 & $9.38 \pm 0.47$ (60)ef & $34.32 \pm 0.94(85) \mathrm{e}$ & $15.55 \pm 0.31(89) 1 \mathrm{~lm}$ \\
\hline & T6 & $5.75 \pm 0.48(37) \mathrm{jk}$ & $29.30 \pm 0.81(73) \mathrm{ijk}$ & $14.67 \pm 0.30(84)$ nop \\
\hline & $\mathrm{T} 7$ & $5.18 \pm 0.69(33) \mathrm{k}$ & $23.90 \pm 0.66(59) p q$ & $14.32 \pm 0.29(82) \mathrm{p}$ \\
\hline
\end{tabular}

T1: Control, T2: EC $6 \mathrm{dS} \mathrm{m}{ }^{-1}$, T3: EC $12 \mathrm{dS} \mathrm{m}^{-1}$, T4: EC $6 \mathrm{dS} \mathrm{m}{ }^{-1}+50 \mathrm{Kg} \mathrm{ha}^{-1} \mathrm{~K}^{+}$, T5: EC $6 \mathrm{dS} \mathrm{m}^{-1}+75 \mathrm{Kg} \mathrm{ha}^{-1} \mathrm{~K}^{+}$, T6: EC $12 \mathrm{dS} \mathrm{m}^{-1}+50 \mathrm{Kg} \mathrm{ha}^{-1} \mathrm{~K}^{+}$, T7: EC $12 \mathrm{dS} \mathrm{m}^{-1}+75 \mathrm{Kg} \mathrm{ha}^{-1} \mathrm{~K}^{+}$.

Each value is an average of 4 replicates \pm S.E., and values in parenthesis are the percent of control.

adverse effects of $\mathrm{NaCl}$ stress was significantly reduced with potassium application also plant growth and development in soybean genotypes improved. That was accomplished to incompatible effects of $\mathrm{K}^{+}$with $\mathrm{Na}^{+}($Lynch and Lauchli, 1985; Abbasi et al., 2014). Similarly, improvement in plant growth and dry mass assembly with potassium application was stated in different crops e.g. rice (Bohra and Doerffling, 1993), maize (Abbasi et al., 2014) in saline condition.

Relative water contents and membrane stability index are the chief factors which measure the extent of tolerance in plant and with increasing salt stress that were reduced significantly (Noreen and Ashraf, 2010). Under salinity stress, reduction in RWC in all soybean genotypes proved the previously reported consequences (Sairam et al., 2002; Abbasi et al., 2014). Potassium application improved relative water contents and membrane stability index under
$\mathrm{NaCl}$ stress because water uptake improved with potassium application for turgidity maintenance in different crops (Subbarao et al., 2000a). Salt stress significantly reduced leaf area while application of potassium increased leaf area in soybean genotypes as also stated by Ayub et al. (2012) in cluster beans.

It is well documented that the key factor for growth and final biomass production is photosynthetic rate of plants. The adverse effects of salinity minimize photosynthetic rate significantly by reduction in photosynthetic rate (A), transpiration rate $(\mathrm{E})$, stomatal conductance $(\mathrm{Gs})$, internal $\mathrm{CO}_{2}$ concentration $(\mathrm{Ci})$ and chlorophyll contents (Chen et al., 2013). Significant reduction in gas exchange attributes resulted with salinity stress in all soybean genotypes but application of potassium improved all gas exchange parameters and the best performance was documented at 
maximum dose of $\mathrm{K}$ with $6 \mathrm{dS} \mathrm{m} \mathrm{m}^{-1}$ salinity level. Reduction in gas exchange parameters was greater in potassium inefficient soybean genotypes (Ajmeri and William-82) under saline condition while potassium efficient soybean genotypes showed minimum reduction in gas exchange parameters.

Salinity stress produces reactive oxygen species that cause damage in intera cellular structure which results reduction in photosynthetic rate (Chen and Heuer, 2013). Antioxidant enzymes provide protection to cell structures and organelles against ROS under salt stress condition (Reddy et al., 2004). In the present study, significant increase in the activities of SOD, POD, and CAT were recorded in all soybean genotypes which formed as a result of oxidative stress but higher activities were recorded with higher dose of potassium $(9 \mathrm{mM})$ with EC $6 \mathrm{dS} \mathrm{m} \mathrm{m}^{-1}$. In scavenging reactive oxygen species SOD is the main enzyme deliberated to be the first line of defense against ROS (Hamilton and Heckathorn, 2001) which change $\mathrm{O}^{2-}$ to $\mathrm{H}_{2} \mathrm{O}_{2}$ the less noxious form of oxygen (Costa et al., 2005). The CAT and POD abolish the $\mathrm{H}_{2} \mathrm{O}_{2}$ produced by SOD into other less toxic formulae (Foyer et al., 1994). Comparatively greater activities of antioxidant enzymes have been recorded in soybean genotypes No. 62 and No. 13 than Ajmeri and William-82. Consequently, soybean genotypes react contrariwise as a result of differences in their antioxidant systems, salt stress and application of potassium (Mohammadkhani and Heidari, 2007; Nawaz and Ashraf, 2007). Nevertheless, potassium application under salt stress further upgraded the activities SOD, POD and CAT in all soybean genotypes. These result also comparable to earlier argument that under salinity stress potassium application significantly improved antioxidant activities in plants (Zheng et al., 2008; Soleimanzadeh et al., 2010; Abbasi et al., 2015).

Oil percentage and protein contents per unit area, increased with adequate potassium nutrition also cost of production decreased and yield and profit increased (Khan et al., 2010). Substantial effect was verified in growth and yield increment by application of potassium in soybean genotypes and similar findings were examined in sunflower and safflower (Bakht et al., 2006; Gerendás et al., 2008; Asadia, 2010). Availability of nitrogen to plants is upgraded by phosphorus and potassium application with increasing the biological nitrogen fixation that is used for the production of crude protein in cluster bean (Ayub et al., 2012). Similar consequences were found in previous studies in several crop species e.g. lucerne (Patel and Kotecha, 2006), mungbean (Hussainand Arshad, 2011). Reducing protein with higher salinity and this might be due to disruption in nitrogen metabolism or reticence of nitrate uptake due to decline of absorbed water and fewer root permeability (Medhat, 2002). In present study all the soybean seeds under control conditions showed higher concentration of protein and oil as compared to $\mathrm{NaCl}$ salt stress and this was associated with production of larger grain size of soybeans as compared to saline soils and similar findings were verified by (GhassemiGolezani et al., 2009). Decrease in protein and oil yield per plant with higher salinity usually related with reduction in the interval of protein and oil accumulation and grain yield per plant under saline condition (Table 2.) but the amount of protein and oil accumulation of Ajmeri and william-82 was slightly less than No. 62 and No. 13. Higher grain, oil and protein per plant of No. 62 and No. 13 soybean genotypes were due to production of more grains per plant than other soybean genotypes as also stated by (Ghassemi-Golezani et al., 2009).

Conclusion: Salt stress strictly reduced plant growth and yield by disturbing plant morphological, physiological, protein and oil contents of all soybean genotypes. Effects of salinity stress were more distinct on soybean genotypes Ajmeri and William-82 than No. 62 and No. 13 soybean genotypes. Though, potassium application significantly reduced adverse effects of salinity by humanizing the plant growth, gas exchange attributes, improving antioxidant enzyme activities, protein and oil quality of all soybean genotypes. Potassium dose $\left(75 \mathrm{~kg} \mathrm{~K}^{+} \mathrm{ha}^{-1}\right)$ was found more effective at EC $6 \mathrm{dS} \mathrm{m}^{-1}$ salt stress level in easing damaging effects of salinity. Potassium efficient soybean genotypes No. 62 and No. 13 produced high biomass, chlorophyll contents, antioxidant enzymes, gas exchange parameters under salt stress condition as compared to salt sensitive soybean genotypes Ajmeri and William-82.

\section{REFERENCES}

Abbasi, G., J. Akhtar, M. Anwar-ul-Haq, S. Ali, Z. CHEN and W. Malik. 2014. Exogenous potassium differentially mitigates salt stress in tolerant and sensitive maize hybrids. Pakistan J. Bot. 46:135-146.

Abbasi, G.H., J. Akhtar, R. Ahmad, M. Jamil, M. Anwar-ulHaq, S. Ali and M. Ijaz. 2015. Potassium application mitigates salt stress differentially at different growth stages in tolerant and sensitive maize hybrids. Plant Growth Regul. 10.1007/s10725-015-0050-1:1-15.

Agarwal, A.K. 2007. Biofuels (alcohols and biodiesel) applications as fuels for internal combustion engines. Prog. Energy Combust. Sci. 33 :233-271.

Akhtar, J., Z.A. Saqib, M. Sarfraz, I. Saleem and S. Haq. 2010. Evaluating salt tolerant cotton genotypes at different levels of $\mathrm{NaCl}$ stress in solution and soil culture. Pak. J. Bot. 42 :2857-2866.

Akinori, S., K. Sayano, H. Kono and M.M. Gromiha. 2000. Multicanonical Mont Carlo calculation of the freeenergy map of the base-amino acid interaction. J. Comput. Chem. 21:954-962. 
Anonymous. 2009. Agricultural Statistics of Pakistan. Ministry of Food, Agriculture and Live Stock (Economic Wing), Islamabad. 65-66.

Anonymous. 2012. Economic Adviser's Wing, Finance Division, Government of Pakistan, Islamabad.

Asadia, S. 2010. Influence of different K fertilizer sources on sunflower production. Paper read at 19th World Congress of Soil Science.

Ayub, M., M. Nadeem, M. Naeem, M. Tahir, M. Tariq and W. Ahmad. 2012. Effect of Different Levels of P and K on Growth, Forage Yield and Quality of Cluster Bean (Cyamopsistetra gonolobus L.). J. Anim. Plant Sci. 22:479-483.

Bakht, J., S. Ahmad, M. Tariq, H. Akber and M. Shafi. 2006. Performance of various hybrids of sunflower in Peshawar valley. J. Agric. Biol. Sci. 1:......????

Balasubramaniyan, P., P.P. Balasubramaniyam and S.P. Palaniappan. 2001. Principles and practices of agronomy. Agrobios.586.

Blumwald, E., A. Grover and A.G. Good. 2004. Breeding for abiotic stress resistance: challenges and opportunities. Paper read at New directions for a diverse planet. Proceedings of the 4th International Crop Science Congress, Brisbane, Australia.

Bohra, J.S. and K. Doerffling. 1993. Potassium nutrition of rice (Oryza sativa L.) varieties under $\mathrm{NaCl}$ salinity. Plant Soil. 152 :299-303.

Chance, M. and A.C. Maehly. 1955. Assay of catalases and peroxidases. Methods Enzymol. 2:764-817.

Chen, P., H. Wang, X. Tang, M. Brestic and H. Shao. 2013. Comparative physiological study between cultivated and wild soybean species under salt stress. Jokull $\mathrm{J}$. 63:1-11.

Chen, S. and B. Heuer. 2013. Effect of genotype and exogenous application of glycinebetaine on antioxidant enzyme activity in native gels of 7-day-old salt-stressed tomato (Solanumlycopersicum) seedlings. Sci. Horticult. 162:106-116.

Chen, Z., M. Zhou, I.A. Newman, N.J. Mendham, G. Zhang and S. Shabala. 2007. Potassium and sodium relations in salinised barley tissues as a basis of differential salt tolerance. Funct. Plant Biol. 34 : 150-162.

Cherel, I. 2004. Regulation of $\mathrm{K}^{+}$channel activities in plants: from physiological to molecular aspects. J. Exp. Bot. 55 :337-351.

Costa, P.H.A.D., A.D.D.A. Neto, M.A. Bezerra, J.T. Prisco and E. Gomes-Filho. 2005. Antioxidant-enzymatic system of two sorghum genotypes differing in salt tolerance. Braz. J. Plant Physiol. 17 :353-362.

Epstein, E. and A. Bloom. 2005. Inorganic components of plants. Mineral nutrition of plants: principles and perspectives, $2^{\text {nd }}$ Ed. Sinauer Associates, Inc., Massachusetts, 44-45.
Essa, T. and D. Al-Ani. 2001. Effect of salt stress on the performance of six soybean genotypes. Pak. J. Biol. Sci. 4:175-177.

Flowers, T.J. and T.D. Colmer. 2008. Salinity tolerance in halophytes*. New Phytologist. 179 :945-963.

Foyer, C., P. Descourvieres and K. Kunert. 1994. Protection against oxygen radicals: an important defence mechanism studied in transgenic plants. Plant Cell Environ. 17 :507-523.

Gerendás, J., J. Abbadi and B. Sattelmacher. 2008. Potassium efficiency of safflower (Carthamus tinctorius L.) and sunflower (Helianthus annuиs L.). J. Plant Nutr. Soil Sci. $171: 431-439$.

Ghafoor, A., M. Qadir, M. Sadiq, G. Murtaza and M. Brar. 2004. Lead, copper, zinc and iron concentrations in soils and vegetables irrigated with city effluent on urban agricultural lands. J. Indian Soc. Soil Sci. 52 :114-117.

Ghassemi-Golezani, K., M. Taifeh-Noori, S. Oustan and M. Moghaddam. 2009. Response of soybean cultivars to salinity stress. J. Food Agric. Environ. 7 :401-404.

Giannopolitis, C.N. and S.K. Ries. 1977. Superoxide dismutase-I. Occurrence in higher plants. Plant Physiol. 59:309-314.

Hajer, A., A. Malibari, H. Al-Zahrani and O. Almaghrabi. 2006. Responses of three tomato cultivars to sea water salinity 1 . Effect of salinity on the seedling growth. Afr. J. Biotechnol. 5 :...????

Hamilton, E.W. and S.A. Heckathorn. 2001. Mitochondrial adaptations to $\mathrm{NaCl}$. Complex I is protected by antioxidants and small heat shock proteins, whereas complex II is protected by proline and betaine. Plant Physiol. 126:1266-1274.

Hussain, Z. and M. Arshad. 2011. Relationship among root characteristics and differential potassium uptake and use efficiency of selected cotton genotypes under potassium deficiency stress.

Hussain, Z., R. Khattak, M. Irshad and A. Eneji. 2013. Ameliorative effect of potassium sulphate on the growth and chemical composition of wheat (Triticum aestivum L.) in salt-affected soils. J. soil sci. plant nut. 13 :401415.

Hymowitz, T., J.W. Dudley, C.F. I. and C.M. Brown. 1974. Estimations of protein and oil concentration in corn, soybean and oat seed by near-infrared light reflectance. Crop Sci. 14:713-717 715.

Iqbal, M., J. Akhtar, M. Haq, M. Nasim, A. Saeed and M. Naveed. 2007. Variation in growth and ion uptake in rice cultivars under $\mathrm{NaCl}$ stress in hydroponics. Pak. J. Agri. Sci. 44:393-400.

Kavitha, P.G., A.J. Miller, M.K. Mathew and F.J.M. Maathuis. 2012. Rice cultivars with differing salt tolerance contains similar cation channels in their rot cells. J. Exp. Bot. 63:3289-3296. 
Khan, M.W., L.K. Almas and B.A. Stewart. 2010. Effects of Macronutrients on Seed Quality and Profitability Analysis of Sunflower Production in Northwest Pakistan. Paper read at 2010 Annual Meeting, February 6-9, 2010, Orlando, Florida.

Krishnan, H.B. 2001. Biochemistry and molecular biology of soybean seed storage proteins. J. New Seeds. 2 :1-25.

Liang, Y., W. Sun, Y.G. Zhu and P. Christie. 2007. Mechanisms of silicon-mediated alleviation of abiotic stresses in higher plants: a review. Environ. Pollut. 147 :422-428.

Lynch, J. and A. Lauchli. 1985. Salt stress disturbs the calcium nutrition of barley (Hordeum vulgare L.). New Phytol. 99 :345-354.

Medhat, M. 2002. Comparative study on growth, yield and nutritive value for some forage plants grown under different levels of salinity, Ph. D. Thesis Faculty of Science, Botany Department, Cairo University, Egypt.

Misra, N. and U. Dwivedi. 2004. Genotypic difference in salinity tolerance of green gram cultivars. Plant Sci. 166 :1135-1142

Mohammadkhani, N. and R. Heidari. 2007. Effects of drought stress on protective enzyme activities and lipid peroxidation in two maize cultivars. Pak. J. Biol. Sci. 10:3835-3840.

Munns, R. and M. Tester. 2008. Mechanisms of salinity tolerance. Annu. Rev. Plant Biol. 59:651-681.

Nawaz, K. and M. Ashraf. 2007. Improvement in salt tolerance of maize by exogenous application of glycinebetaine: growth and water relations. Pak. J. Bot. $39: 1647-1653$.

Neto, A.D.D.A., J.T. Prisco, J.E. Filho, C.E.B.D. Abreu and E.G. Filho. 2006. Effect of salt stress on antioxidative enzymes and lipid peroxidation in leaves and roots of salt-tolerant and salt-sensitive maize genotypes. Environ. Exp. Bot. 56 :87-94.

Noreen, S. and M. Ashraf. 2010. Modulation of salt ( $\mathrm{NaCl})$ induced effect on oil composition and fatty acid profile of sunflower (Helianthus annuusL.) by exogenous application of salicylic acid. J. Sci. Food Agric. 90:2608-2616.

Patel, P. and A. Kotecha. 2006. Effect of phosphorus and potassium on growth characters, forage yield, nutrient uptake and quality of lucerne (Medicago sativa). Indian J. Agron. 51 :242-244.

Reddy, A.R., K.V. Chaitanya and M. Vivekanandan. 2004. Drought-induced responses of photosynthesis and antioxidant metabolism in higher plants. J. Plant Physiol. $161: 1189-1202$.

Rejili, M., A.M. Vadel, A. Guetet and M. Neffatti. 2007. Effect of $\mathrm{NaCl}$ on the growth and the ionic balance $\mathrm{K}^{+} / \mathrm{Na}^{+}$of two populations of Lotus creticus (L.) (Papilionaceae). S. Afr. J. Bot. 73 :623-631.

Sairam, R.K., K.V. Rao and G.C. Srivastava. 2002. Differential response of wheat genotypes to long term salinity stress in relation to oxidative stress, antioxidant activity and osmolyte concentration. Plant Sci. 163 :1037-1046.

Shabala, S., L. Shabala and E. Van Volkenburgh. 2003. Effect of calcium on root development and root ion fluxes in salinised barley seedlings. Funct. Plant Biol. $30: 507-514$.

Shi, G. and Q. Cai. 2010. Zinc tolerance and accumulation in eight oil crops. J. Plant Nutr. 33:982-997.

Sohail, M., A. Saied, J. Gebauer and A. Buerkert. 2010. Effect of $\mathrm{NaCl}$ Salinity on Growth and Mineral Composition of Ziziphusspina-christi (L.) Willd. J. Agric. Rural Dev. Trop. Subtrop. 110 :107-114.

Soleimanzadeh, H., D. Habibi, M. Ardakani, F. Paknejad and F. Rejali. 2010. Effect of potassium levels on antioxidant enzymes and malondialdehyde content under drought stress in sunflower (Helianthus annuus L.). Am. J. Agricl. Biol. Sci. 5:56.

Subbarao, G., R. Wheeler, G. Stutte and L. Levine. 2000a. Low potassium enhances sodium uptake in red-beet under moderate saline conditions. J. Plant Nutr. 23 :1449-1470.

Tiwari, S.P., O.P. Joshi, A.K. Vyas and S.D. Billore. 2002. Potassium nutrition in yield and quality improvement of soyabean. Paper read at Proceedings of the International Symposium on Potassium for Sustainable Crop Production.

Yilmaz, K., I.E. Akinci and S. Akinci. 2004. Effect of salt stress on growth and $\mathrm{Na}, \mathrm{K}$ contents of pepper (Capsicum annuum L.) in germination and seedling stages. Pak. J. Biol. Sci. 7 :606-610.

Zheng, Y., A. Jia, T. Ning, J. Xu, Z. Li and G. Jiang. 2008. Potassium nitrate application alleviates sodium chloride stress in winter wheat cultivars differing in salt tolerance. J. Plant Physiol. 165:1455-1465.

Zhu, J.K. 2002. Salt and drought stress signal transduction in plants. Annu. Rev. Plant Biol. 53 :247-273.

Zora, D.A. 2006. Salt stress. In Physiology and molecular biology of stress tolerance in plants: Springer. ISBN 978-1-4020-4225-6. 